DOI 10.32755/sjcriminal.2021.01.080

Puzyrov M. S., Doctor of Sciences (Law), Head of the Department of Scientific Activity and International Cooperation, Academy of the State Penitentiary Service, Chernihiv, Ukraine ORCID: 0000-0002-7814-9476;

Klysha A. I.,

Officer of the 461st academic group, Academy of the State Penitentiary Service, Chernihiv, Ukraine ORCID: 0000-0003-2681-7185

\title{
PECULIARITIES OF REGIME IMPLEMENTATION IN THE SOCIAL REHABILITATION SECTIONS OF UKRAINE'S CORRECTIONAL COLONIES
}

The essence and matter of the concept of regime and the peculiarities of its implementation in the social rehabilitation sections of Ukraine's correctional colonies are considered in the article. The characteristics of the essence of the regime is given, which provides: security system (provides convicts' isolation); a system of supervision over convicts (ensures convicts' performing their duties); technical means of supervision and control; law enforcement intelligence-gathering activities; regime of special conditions in colonies; application of measures of physical influence, special means and weapons. The essence of the principles of progressive system of executing punishments is considered.

Key words: regime, social rehabilitation section, correctional colony, peculiarities of regime implementation, progressive system.

Target setting. Since independence, Ukraine has been moving towards democratic reforms. The main vector of the activity of state institutions in the field of punishments executing is aimed at ensuring human rights and freedoms, and the legislation is brought in line with the requirements of international norms and standards. It should be noted that throughout its existence, Ukraine's executive system has been repeatedly criticized by national experts and human rights activists, as well as by international experts, and the state of affairs in this system has been recognized as critical and in need of immediate change.

Unfortunately, the measures taken to restructure the colonies did not bring them out of the crisis, as a result of which one in four of those who had previously served their sentences committed a criminal offense again. The conditions of convicts and detainees' detention do not fully meet international standards. 
Actual scientific researches and issues analysis. V. M. Bryzhalov, V. I. Monakhov, M. Ye. Makahon, M. O. Struchkov, Yu. M. Umynets, B. S. Utievskyi, et al. revealed the problems of the regime in penal institutions in their works. The means of securing the regime were partially considered within the framework of studying the regime of executing and serving of sentences by scholars. The papers of such scholars in the field of criminal and executive law as M. O. Bieliaiev, T. A. Denysova, E. M. Zakhtser, P. P. Kozlov, Yu. V. Nikitin, Y. S. Noi, A. Kh. Stepaniuk, S. O. Stefanov, V. S. Tikunov, Yu. M. Tkachevskyi, V. M. Trubnykov, H. O. Tumanov, P. L. Fris et al. were devoted to this issue. However, the views of these scholars are ambiguous and together do not give a proper idea of the regime and its means in penal institutions.

The current system of execution of sentences and pre-trial detention, built in Soviet times, does not correspond to the current level of socio-economic development of society and the principles of humanism and respect for human rights and freedoms in the process of executing sentences. The conditions of convicts and detainees' detention are extremely unsatisfactory; the state of medical care for convicts, patients with physical and mental illnesses, infectious diseases, tuberculosis and HIV/AIDS remains inadequate; low level of organization of social, educational and psychological work with convicts does not provide conditions for effective individual correction of their behavior, leads to many cases of suicide in penitentiaries, unpreparedness for life after release from penal institutions and, as a consequence, a significant number of cases of recidivism.

Given that the issue of regime implementation in the social rehabilitation sections of Ukraine's correctional colonies has its differences from the regime in other structural areas, our attention will be focused on highlighting the peculiarities of the regime requirements in social rehabilitation sections.

The purpose of the article is to consider the subject and essence of the concept of regime and the peculiarities of its implementation in the social rehabilitation sections of Ukraine's correctional colonies.

The statement of basic materials. Regarding the definition of the regime, the foreign scholar M. O. Struchkov interpreted the regime as a certain way, way of convict's life, which reproduces the 
essence of punishment. Its restrictions are embodied in the convict's compliance with certain rules of conduct due to the peculiarities of imprisonment, the need for cohabitation in one territory, in one room of many people of anti-social orientation [1, p. 167].

Ukrainian researcher $\mathrm{Yu}$. M. Umynets understands the regime as a complex, which includes the main structural elements as: work, study, physical culture and its main functions, which in the form of clear organization and management of these elements are more rational and consistent with the principles of logical construction of any system of penalties related to imprisonment. Thus, the regime is a set of all methods and techniques of convicts' treatment or a system of management of the process of imprisonment in order to achieve the goal of punishment [2, p. 20].

In turn, V. I. Monakhov noted that the regime of serving convicts regulates their behavior, because, influencing the behavior, through it affects the mind, so, in his opinion, the regime is one of the main means of educating discipline in its broadest sense. A person's adherence to the regime educates him because it produces certain habits and necessary qualities, affects higher nervous activity and leads to the establishment of complex neural connections, called dynamic stereotypes, but the educational impact of regime rules is mediated by the convict's inner attitude to this regime. Therefore, the scholar considers carrying out explanatory work with a convict on the significance and expediency of the regime conditions of serving a sentence for their correction to be an important condition. Regime rules of conduct should be appropriate and not too complicate convicts' life and everyday life, because it will negatively affect the correctional process [3, p. 194-197].

At present, the legal field clearly states that the regime in the colonies should minimize the difference between living conditions in the colony and in freedom, which should increase the responsibility of convicts for their behavior and awareness of human dignity.

In our opinion, the regime should be considered as a set of substantive and procedural norms governing the activities of the administration of correctional colonies, which by law are entrusted with the functions of execution of punishment. It should be noted that it is the administration of correctional colonies that must ensure 
the implementation of the regime requirements, as well as the set of conditions and rules for serving sentences.

At the same time, the generalization of scholars' views allows us to conclude that the regime is a certain order of execution and serving of punishment, which permeates the whole way of life of the convict, promotes a positive attitude to the established agenda in the penal colony, work, social work and for convicts' correction and resocialization.

Important provisions of the regime and its mandatory compliance with the principles of justice, humanity, legality are contained in international legal acts, namely: the Universal Declaration of Human Rights; Code of Conduct for Law Enforcement Officials; Convention against Torture and Other Cruel, Inhuman or Degrading Treatment or Punishment; a Set of Principles for the Protection of All Persons Who Are Subject to Detention or Imprisonment in any Form, etc.

The list of international legal acts is not full. However, it provides an idea of the legal basis of the regime, in particular, the general principles of ensuring the regime and the main requirements for ensuring law and order.

A special role in the legal support of the regime is played by departmental regulations, in particular the Instruction on the organization of supervision of convicts serving sentences in penitentiary institutions, approved by the order of the Ministry of Justice of Ukraine dated 22.04.2016 № 30/5 - FSU.

At the same time, the legal regulation of the regime and its means is set out in Chapter 16 of the Criminal Executive Code of Ukraine and regulations governing the regime of execution and serving sentences in penal institutions, in particular the Rules of Procedure of penal institutions approved by the Ministry of Justice of Ukraine dated 28.08.2018 № 2823/5 [4].

Thus, the regime establishes the rules of conduct of all participants and subjects of legal relations, their rights and obligations arising from executing and serving punishment. The regime acts as a link in the application of other means of convicts' correction and re-socialization of provided by law.

As a result of considering the subject matter and the essence of the regime, it should be noted that the main means of ensuring the regime in 
accordance with the provisions of Chapter 16 of the Criminal Executive Code of Ukraine include: security system (provides convicts' isolation); a system of supervision over convicts (ensures convicts' performing their duties); law enforcement intelligence-gathering activities; regime of special conditions in colonies; application of measures of physical influence, special means and weapons.

Ensuring the regime in social rehabilitation sections, which are created in correctional colonies of minimum and medium levels of security has its own peculiarities. Thus, in the social rehabilitation section, convicts are not kept under guard, but under supervision, i.e. they can move freely within the territory of the section during the day. In addition, with the permission of the penitentiary administration, convicts may move unattended outside the precinct, but within the settlement, if necessary due to the nature of their work or in connection with training.

Such convicts are allowed to wear civilian clothes, have a registered mobile phone, carry portable personal computers and accessories, money and valuables. Once a month they are given a long-term appointment, and short-term one without restrictions. After six months in a social rehabilitation unit, in the absence of violations of the regime, convicts can live within the settlement where the penal colony is located, with their families, buy a house in accordance with current legislation and start a personal household. Such convicts can work outside the colony (at contractor facilities). However, convicts in a social rehabilitation section are actually obliged to work, as they have to support themselves (eat and provide for themselves).

Based on the progressive penitentiary system implemented within the framework of the Council of Europe Project "Further Support for Penitentiary Reform in Ukraine", four principles of effective imprisonment, which are the norm in developed European penitentiary systems, are implemented in correctional colonies. The first principle is to provide a safe environment for staff and prisoners. The second principle is to understand that prisoners are treated politely and their human dignity is respected. This principle includes checking the conditions in which prisoners are held and the treatment of them by prison staff. It covers areas such as accommodation, hygiene, clothing, nutrition, health and staff-prisoner relations. The 
third principle means that prisoners have the opportunity to participate in targeted activities such as work, education and training for all prisoners through the best use of all available resources. This principle covers such areas as education, work, training, programs of work with illegal behavior, religious activities and physical education. The fourth and final principle is that prisoners are ready for rehabilitation and release. This principle includes support for family relationships, correspondence, visits, telephone calls, life at large, employment opportunities and social relations [5].

Social rehabilitation sections of correctional colonies contribute to convicts' re-socialization, namely, to ensure the restoration and expansion of socially useful ties and relations with society released from prisons, the development of a holistic personality capable of objective attitude to the world and to themselves.

Of course, the return of a person who has committed a criminal offense to a normal life in society involves not only serving a sentence, but most important is to correct and acquire the universal values and norms of behavior in society, respecting the rights and freedoms of themselves and others.

Punishment, in our opinion, does not imply the acquisition of values and norms of life of people who live by the rules of prison, but involves a change of thinking, which in turn changes a person's attitude to the world and his own life.

One can be convinced that the section of social rehabilitation of a correctional colony is much more favorable for changing a person's illegal thinking and opens up opportunities for self-realization and establishing one's own happy life.

Conclusions. Based on the above material, the following conclusions can be drawn:

1) the regime is defined as a certain order of executing and serving a sentence, which permeates the whole way of life of the convict, promotes a positive attitude to the established daily routine in the penal colony, work, social and educational work and aims to correct and re-socialize convicts. The regime of serving a sentence should be considered as a set of substantive and procedural norms governing the activities of the administration of correctional colonies, which by law are entrusted with the functions of execution of punishment; 
2) the essence of the regime provides: security system (provides convicts' isolation); a system of supervision over convicts (ensures convicts' performing their duties); law enforcement intelligencegathering activities; regime of special conditions in colonies; application of measures of physical influence, special means and weapons;

3 ) the peculiarities of the implementation of the regime in a social rehabilitation section of correctional colonies are: the use of persuasion as a set of educational measures that actively influence the consciousness and will of convicts; the use of means of state coercion, which are directly aimed at preventing the commission of violations of the regime, prevention of such violations, restoration of violated regime norms; implementation of prosecutorial supervision, departmental, judicial and public control; operational and preventive work, which is the prerogative of the administration of the penal colony;

4) social rehabilitation sections of correctional colonies contribute to convicts' re-socialization, namely, to ensure the restoration and expansion of socially useful ties and relations with society released from prisons, the development of a holistic personality capable of objective attitude to the world and to themselves.

\section{References}

1. Struchkov, N. A. (1984), Course of correctional labor law. Problems of the General Part, Legal Literature, Moscow.

2. Umynets, Yu. M. (2003), "Actual problems of regime improvement in places of imprisonment", Problems of Penitentiary Theory and Practice, No. 8, pp. 17-22.

3. Monakhov, V. I. (1961), "Regime as a means of educating prisoners", Problems of Development of Soviet Correctional Labor Legislation, Publishing House of the Saratov State Law Institute named after D. I. Kursky, Saratov, pp. 191-205.

4. Ukraine (2018), On Approval the Rules of Procedure of Penal Institutions: order, Ministry of Justice of Ukraine, Kyiv, available at: http://zakon.rada.gov.ua/laws/show/z1010-18 (accessed March 10, 2021).

5. Results of the project of the Council of Europe and the European Union "Further Support for the Penitentiary Reform in Ukraine", available at: http://www.kvs.gov.ua/peniten/control/main/uk/publish/article/818473 (accessed March 10, 2021). 

Академія Державної пенітенціарної служби, м. Чернігів, Україна ORCID: 0000-0002-7814-9476;

Клиша А. І.,

слухач 461-ї навчальної групи, Академія Державної пенітенціарної служби, м. Чернігів, Україна ORCID: 0000-0003-2681-7185

\section{ОСОБЛИВОСТІ РЕАЛІЗАЦІЇ РЕЖИМУ У ДІЛЬНИЦЯХ СОЦІАЛЬНОЇ РЕАБІЛІТАЦЇ̈ ВИПРАВНИХ КОЛОНІЙ УКРАЇНИ}

У статті розглянуто сутність та зміст поняття режиму та особливості його реалізації в дільницях сочіальної реабілітації виправних колоній України. Надано характеристику сутності режиму, яка передбачає: систему охорони (забезпечує ізоляцію засуджених); систему нагляду за засудженими (забезпечує виконання засудженими обов 'язків); технічні засоби нагляду $і$ контролю; оперативно-розшукову діяльність; режим особливих умов у колоніях; застосування заходів фізичного впливу, спеціальних засобів $i$ зброї. Розглянуто зміст принщипів прогресивної системи виконання покарань.

Визначено особливості реалізації режиму у дільниці сочіальної реабілітаиії виправних колоній, якими є: використання переконання як сукупності виховних заходів, шуо активно впливають на свідомість та волю засуджених; застосування засобів державного примусу, які безпосередньо спрямовані на запобігання вчинення порушень режиму, запобігання таких порушень, відновлення порушених режимних норм; здійснення прокурорського нагляду, відомчого, судового та громадського контролю; оперативно-профілактична робота, яка є прерогативою адміністрачії виправної колонії.

3'ясовано, щзо дільниці сочіальної реабілітащії виправних колоній сприяють ресочіалізації засуджених, а саме покликані забезпечити відновлення $i$ розширення сочіально корисних зв'язків і відносин із суспільством звільненої з місиь позбавлення волі особи, розвиток иілісної особистості, здатної до об 'єктивного ставлення як до навколишнього світу, так і до самої себе.

Наголошено на тому, щзо дільниці соціальної реабілітації реалізовують чотири основних принципи, які є нормою в розвинутих європейських пенітенціарних системах, а саме: забезпечення безпечного середовища для персоналу $i$ засуджених; ввічливого ставлення до засуджених, поважаючи їхню людську гідність; переконаність у тому, щзо засуджені мають можливість брати участь у иілеспрямованій діяльності, такій як робота, освіта та навчання для всіх засуджених иляхом найкращцого використання всіх наявних ресурсів; готовність засуджених до реабілітації та виходу на волю.

Ключові слова: режим, дільничя сочіальної реабілітації, виправна колонія, особливості реалізачії режиму, прогресивна система. 